\title{
AVULSED PERMANENT INCISOR - REPLANTATION AFTER TWO DAYS OF THE TRAUMA: REPORT OF A CASE
}

\author{
INCISIVO PERMANENTE AVULSIONADO - REIMPLANTE APÓS DOIS DIAS \\ DO TRAUMA: RELATO DE UM CASO
}

\author{
Lívia de Souza Tolentino * \\ Elen de Souza Tolentino * \\ Eduardo Dias-Ribeiro ** \\ Marina de Lourdes Calvo Fracasso $\cdots$ \\ Alfredo Franco Queiroz ${ }^{* * *}$ \\ Nair Narumi Orita Pavan ${ }^{* * * *}$
}

\begin{abstract}
Tooth avulsion is a complex injury that affects the pulp tissue, periodontal ligament and alveolar bone. It is more frequent in children aged 7 to 11 years. The prognosis is directly related to the period during which the tooth is outside the socket; there is consensus in the literature that the shorter this period, the higher will be the possibility of pulp revascularization and reattachment of periodontal ligament fibers. The need of maintenance of the avulsed tooth in an adequate medium is also known. This study reports a case of complex replantation after avulsion, in which the care was provided 48 hours after the trauma and the tooth was kept dry by the patient, thus suggesting a treatment option for these cases. The avulsed tooth was cleaned and submitted to endodontic treatment; a rigid retainer was used for 7 days and the calcium hydroxide dressing was constantly replaced for 12 months. After 28 months, the tooth exhibited clinical aspect of normality and the radiographic examination revealed a slight alteration at the apical portion of the root. It was concluded that this treatment planning may be a good option in cases of tooth avulsion with late replantation; even though the conditions of care were unfavorable and contraindicated by the scientific literature and the prognosis was impaired, a considerable benefit was achieved for the patient, since the treatment allowed its immediate reintegration to the social relationships, as well as maintenance of facial growth and development.
\end{abstract}

DESCRIPTORS: Tooth avulsion • Treatment • Tooth Replantation

\section{RESUMO}

A avulsão dentária é uma injúria complexa que afeta o tecido pulpar, ligamento periodontal e osso alveolar. É mais frequente em crianças com idade entre 7 a 11 anos. O prognóstico está diretamente relacionado ao período de tempo em que o dente avulsionado permanece fora do alvéolo. É consenso na literatura que, quanto menor esse período, maior probabilidade de revascularização pulpar e restabelecimento das fibras do ligamento periodontal. É necessária a manutenção do dente avulsionado em um meio adequado. O objetivo deste estudo é relatar um caso de um procedimento complexo de reimplante dentário tardio, em que o dentista somente foi procurado após 48 horas da avulsão e o dente foi mantido seco durante este período, assim como sugerir uma opção de tratamento para esses casos. O dente avulsionado foi limpo e submetido a tratamento endodôntico; uma contenção rígida foi usada durante 7 dias e trocas periódicas do hidróxido de cálcio foram mantidas durante 12 meses. Após 28 meses, o dente exibiu aspecto clínico de normalidade e o exame microscópico revelou uma ligeira alteração no ápice radicular. Conclui-se que esse plano de tratamento pode ser uma boa opção para casos de avulsão com reimplante tardio. Ainda que sob condições de manutenção do dente desfavoráveis e contraindicadas pela literatura científica, um considerável benefício foi alcançado para o paciente, uma vez que o tratamento permitiu uma reintegração imediata de seu relacionamento social, assim como permitiu a manutenção do crescimento e desenvolvimento facial.

DESCRITORES: Avulsão dentária • Tratamento • Reimplante dentário

* Master degree student, Department of Dentistry, State University of Maringá (UEM), Maringá, Brazil.

** PhD degree student, Department of Stomatology, Dental School of Bauru, University of São Paulo (FOB-USP), Bauru, Brazil.

*** Master degree student, Department of Stomatology, Dental School of Bauru, University of São Paulo (FOB-USP), Bauru, Brazil.

**** Professor, Department of Dentistry, State University of Maringá (UEM), Maringá, Brazil. 


\section{INTRODUCT I ON}

Tooth avulsion is the complete displacement of the tooth outside the socket (Senes et al. ${ }^{1}, 2008$; Walton e Torabinejad $\left.^{2}, 1997\right)$. It is a complex injury that affects the pulp tissue, periodontal ligament and alveolar bone (Chappuis e von $\mathrm{Arr}^{3}$, 2005; Polat e Tacir $\left.{ }^{4}, 2008\right)$, possibly also affecting the apical bundle (Soares e Goldberg $^{5}, 2001$; Soares et al. $\left.{ }^{6}, 2008\right)$. Interruption of the blood supply leads to pulp necrosis, since revascularization of the pulp throughout its extent is possible, yet not very probable (Cardoso e Gonçalves ${ }^{7}$, 2002; Pohl et al. $\left.{ }^{8}, 2005\right)$.

According to Consolaro9 ${ }^{9}, 2005$ this traumatic injury is more prevalent among males, primarily affects the maxillary central incisors, in individuals aged 7 to 10 years, and especially patients presenting Class II occlusion. Tooth avulsion accounts for 0.5 to $16 \%$ of all traumas to the permanent teeth (Flores et al. ${ }^{10}, 2007$; Polat e Tacir $\left.{ }^{4}, 2008\right)$, and 7 to $13 \%$ to the deciduous teeth (Andreasen et al. ${ }^{11}$, 2000). Accidents during cycling, sports, fights, falls, against objects and in recreation parks are the main etiologic factors of tooth avulsion.

The functional and esthetic importance of affected teeth and mainly the young age of patients when this trauma occurs have encouraged several studies in an attempt to assure the longevity of the replanted tooth (Barret et al. ${ }^{12}$, 2005; Chappuis e von $\mathrm{Arx}^{3}, 2005$; Pohl et al. ${ }^{13}, 2005$; Senes et al. $\left.{ }^{1}, 2008\right)$.

Undoubtedly, tooth replantation is the best treatment option for tooth avulsion in the permanent dentition (Flores et al. ${ }^{10}, 2007$; Soares et al. $\left.{ }^{6}, 2008\right)$, since it allows the reestablishment of esthetics and function, even if temporarily (Senes et al. $\left.{ }^{1}, 2008\right)$. Evidences have shown that the greater determinant for tooth survival is immediate replantation at the moment of the accident (Kenny e Casas ${ }^{14}$, 2005; Lekic et al. $\left.{ }^{15}, 1998\right)$. A delay greater than 5 minutes in the replantation (Toronto Dental Trauma Research Group ${ }^{16}$, 2005) will lead to resorption and occasionally to loss of the tooth if it is not stored in an adequate medium (Andreasen et al. ${ }^{17}$, 1995).
The favorable treatment prognosis is directly related to the period during which the tooth is kept outside the socket, since this exposure causes damages to the periodontal ligament cells due to dehydration (Barret e Kenny ${ }^{18}$, 1997; Barret et al. ${ }^{12}$, 2005; Sonoda et al. $\left.{ }^{19}, 2008\right)$. There is consensus in the literature that the shorter this period (less than 30 minutes), the higher will be the possibility of pulp revascularization and reattachment of periodontal ligament fibers (Chappuis e von $\mathrm{Arx}^{3}$, 2005; Pohl et al. ${ }^{20}, 2005$; Soares e Goldberg5 , 2001; Walton e Torabinejad ${ }^{2}$, 1997). This highlights the need to perform replantation as quickly as possible, as well as the importance of maintaining the tooth in an adequate medium while outside the socket.

If the immediate replantation is not possible and the tooth is not adequate stored, alternative treatments should be employed in the search for satisfactory outcomes

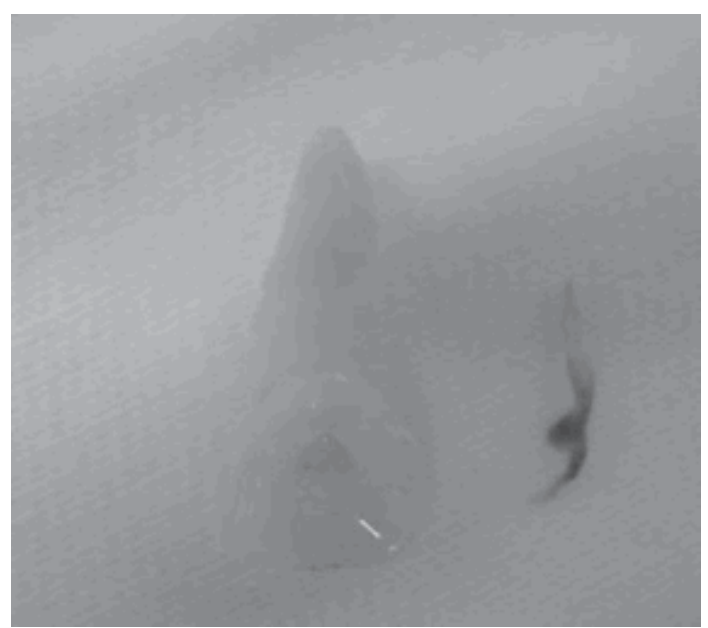

Fig.1 Tooth preparation for replantation, outside the mouth (coronal opening and pulp removal).

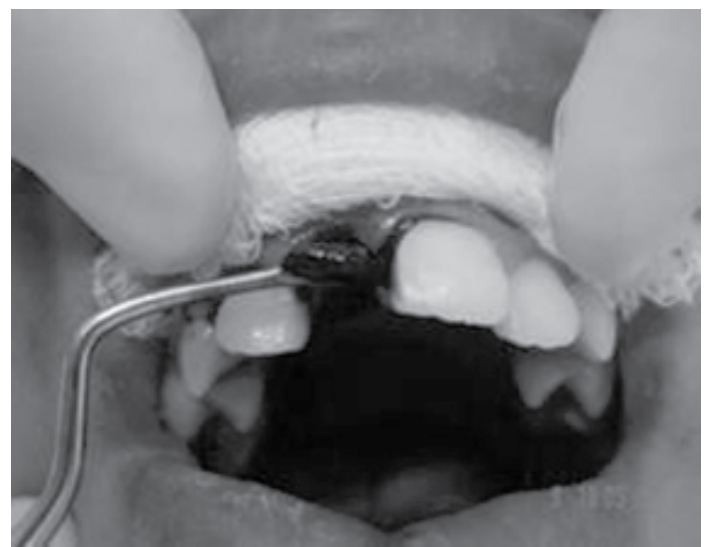

Fig. 2 Socket manipulation - curettage to remove the blood clot.
TOLENTINO LS

TOLENTINO ES

DIAS-RIBEIRO E

FRACASSO MLC

QUEIROZ AF

PAVAN NNO

AVULSED

PERMANENT

INCISOR -

REPLANTATION

AFTER TWO DAYS

OF THE TRAUMA:

REPORT OF A

CASE

\section{1}

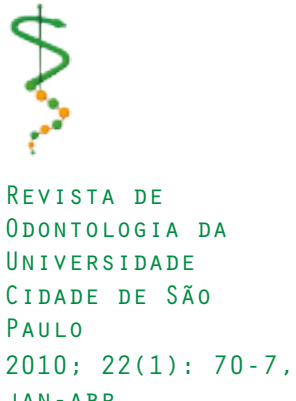

JAN - ABR 


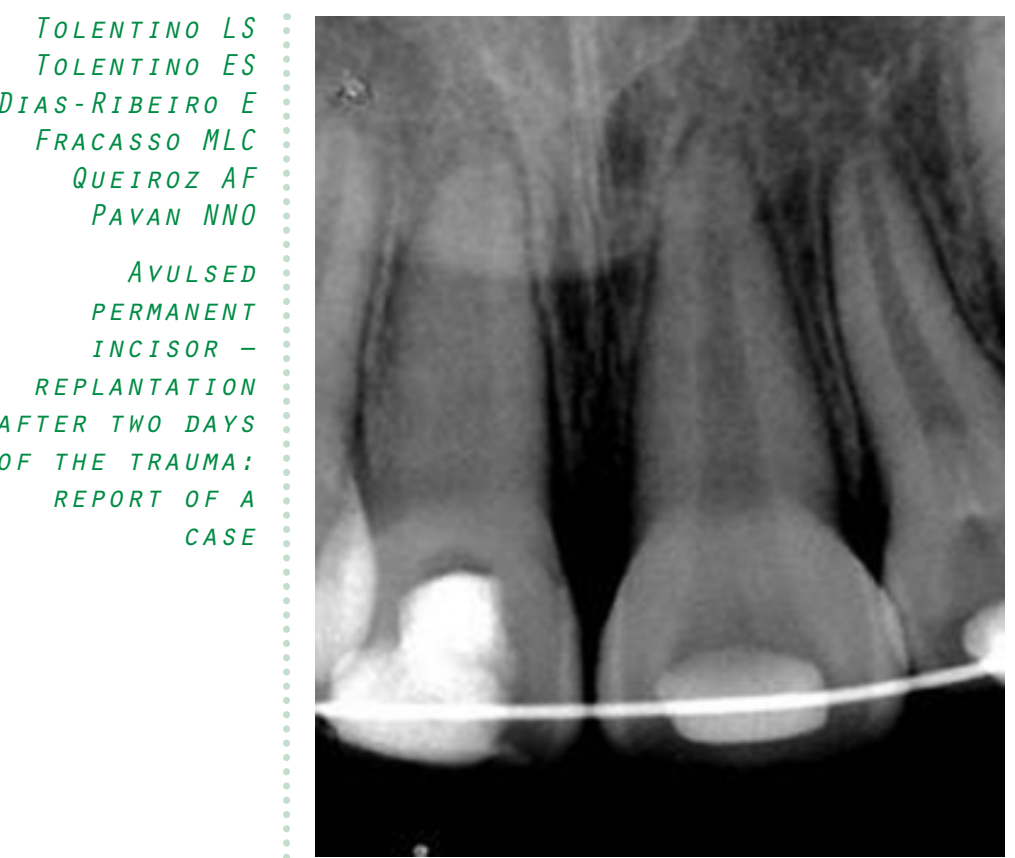

Fig. 3 Periapical radiograph - immediate postoperative aspect with replantation of the maxillary right central incisor and rigid retainer.

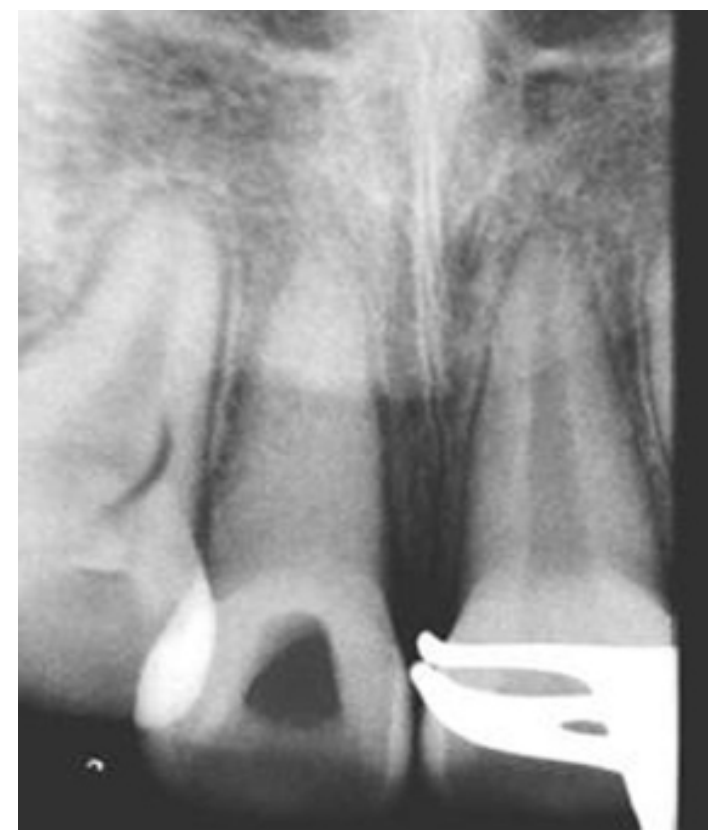

Fig. 4 Periapical radiograph - postoperative aspect at 7 days (removal of retainer and replacement of calcium hydroxide dressing).

for the patients, such as the accomplishment of late replantation. In these cases, the tooth should be carefully cleaned with gauze soaked in saline to remove the necrotic periodontal ligament fibers (Cardoso e Gonçalves ${ }^{7}, 2002$ ), followed by placement of a retainer and root canal treatment to reduce the risk of inflammatory resorption (Senes et al. ${ }^{1}, 2008$ ). The

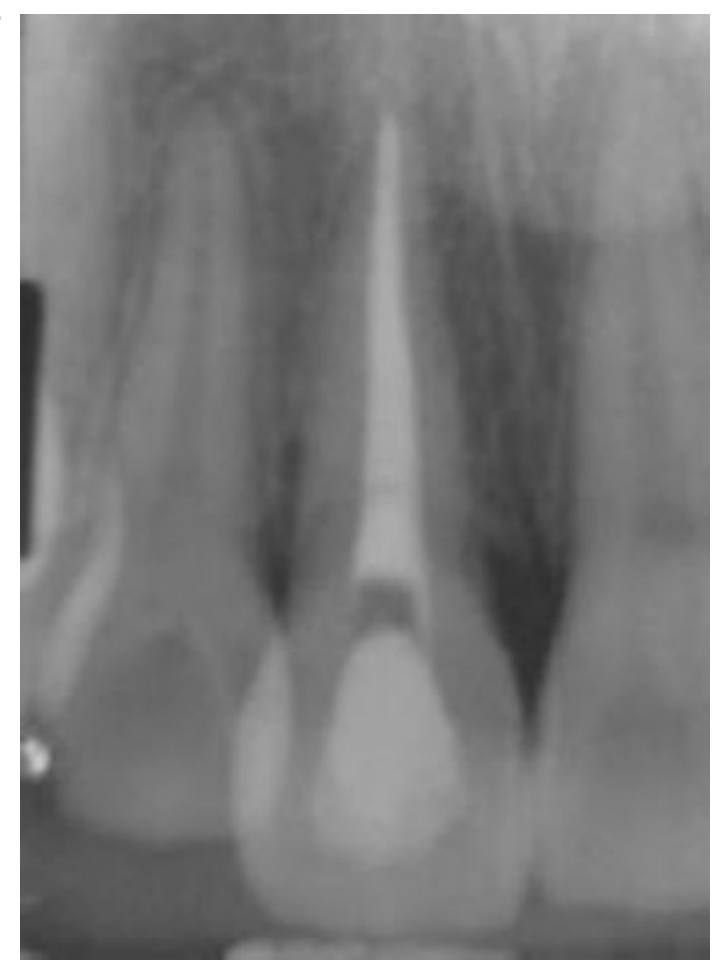

Fig. 5 Periapical radiograph - postoperative aspect at 12 months after replantation (root canal obturation).

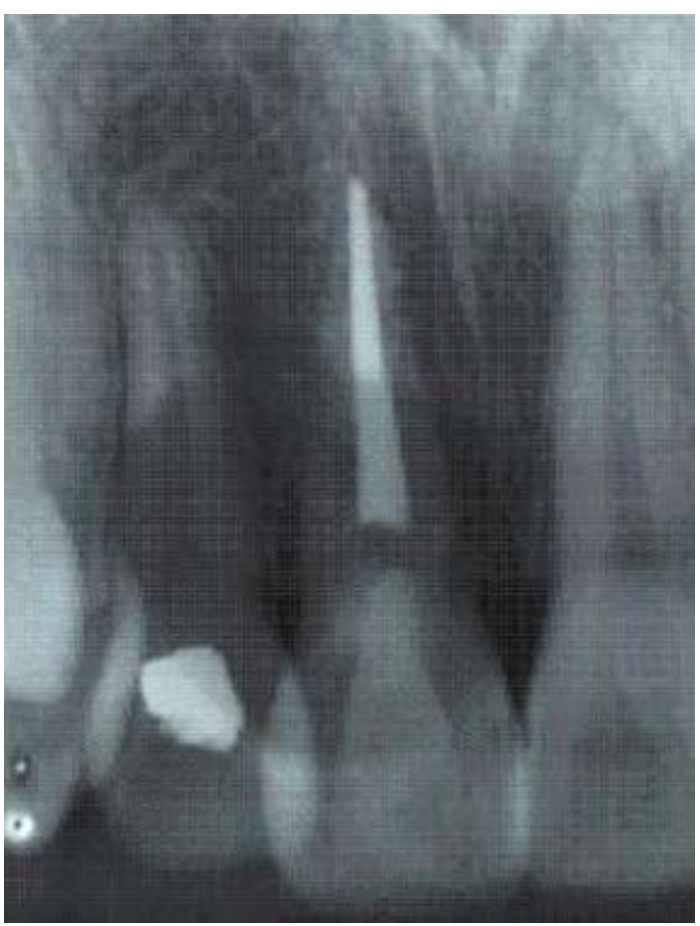

Fig. 6 Periapical radiograph - postoperative aspect at 28 months after replantation.

root surface treatment of avulsed teeth may increase the probability of success of late replantation (Senes et al. ${ }^{1}, 2008$ ).

The prognosis of a replanted tooth presents several variations. In some cases, the tooth may remain in function for several decades, while in others it may be lost in some weeks after replantation (Soares et 
al. $\left.{ }^{6}, 2008\right)$.

This study reports a complex clinical case of replantation after avulsion, with emergency care provided 48 hours after the trauma, in which the tooth was kept dry, with a view to suggest a treatment option for these cases.

\section{CASE REPORT}

A male patient aged 10 years, with avulsion of the maxillary right central incisor, reported that he had lost a tooth two days before while playing soccer. The tooth was stored completely dry in a paper napkin. The patient presented good general status, without fracture of the alveolar bone or history of previous lesions.

The care was provided at the Specialized Center of Dental Trauma of Maringá (CEMTrau Odonto), at the Department of Dentistry of the State University of Maringá, PR, Brazil.

The patient and his caretaker were informed on the procedure and the possible results and authorized the accomplishment of replantation.

The tooth was kept in saline for hydration until coronal opening and instrumentation. After careful cleaning of the tooth with gauze soaked in saline, the tooth was treated outside the mouth for coronal opening, followed by pulp removal (Fig. 1), root canal filling with calcium hydroxide and saline and temporary sealing with zinc oxide-eugenol cement.

The patient was then treated. Initially, the intraoral examination revealed that the bone tissue and adjacent teeth exhibited normal status. Local infiltrative anesthesia was applied at the site of trauma for manipulation of the socket for complete removal of the blood clot and thorough irrigation with saline, preparing the socket for replantation of the maxillary right central incisor (Fig. 2). After replantation, a rigid retainer was used for 7 days and postoperative drugs were prescribed, as follows: antibiotics, analgesics, and antitetanic prophylaxis. A periapical radiograph was taken at the immediate postoperative period, which revealed correct positioning of the tooth (Fig. 3). After 7 days, the rigid retainer was carefully removed and another periapical radiograph was taken, revealing normal aspect of the anatomical structures (Fig. 4).

The patient attended eight follow-up sessions in the subsequent months, for replacement of the calcium hydroxide dressing. Final root canal obturation was performed at 12 months (Fig. 5) after the first attendance using the sealer Endofill $®$ and gutta-percha points. Immediately thereafter, the coronal opening was restored with glass ionomer cement and light-cured acrylic resin.

After 28 months, clinical examination of the avulsed tooth revealed normal aspect, yet the radiographic examination indicated a slight alteration at the apical portion of the root (Fig. 6); however, the patient did not have any complaint.

\section{DISCUSSION}

Avulsion is a severe traumatic injury to the tooth. The pulp and periodontal ligament are affected, and the alveolar bone and gingiva may also suffer injuries (Pohl et al. ${ }^{13}, 2005$; Soares et al. ${ }^{6}, 2008$ ).

In multiple accidents, the intensity and type of trauma, combined to the loose structure of the periodontal ligament of teeth in children aged 7 to 12 years, favor the total displacement of the tooth. The impact causes extraction of the tooth and the functional and esthetic consequences are immediate. For the patient and his or her parents, the psychological impact is greater than the impact causing the avulsion.

Even though these traumas may cause the avulsion of any anterior tooth, the maxillary central incisors are often the most affected (Senes et al. ${ }^{1}, 2008$ ). In the present case report, the avulsion occurred on the maxillary right central incisor in a male patient aged 10 years, corroborating the findings described by Consolaro ${ }^{9}, 2005$ who reports that this trauma affects mostly the maxillary central incisors of children aged 7 to 10 years, affecting the boys three times more often than the girls.

Undoubtedly, tooth replantation is the best treatment option for tooth avulsion (Flores et al. ${ }^{10}, 2007$ ), since it allows the reestablishment of esthetics and function, even if temporarily. Evidences have
TOLENTINO LS

TOLENTINO ES

DIAS-RIBEIRO E

FRACASSO MLC

QUEIROZ AF

PAVAN NNO

$A V U L S E D$

PERMANENT

INCISOR -

REPLANTATION

AFTER TWO DAYS

OF THE TRAUMA:

REPORT OF A

CASE
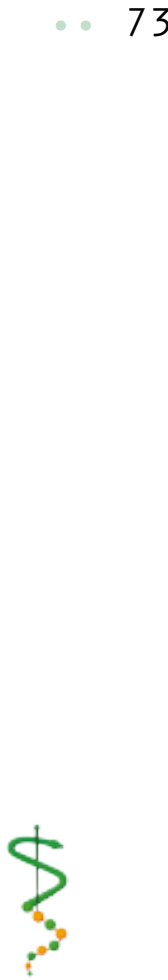

REVISTA DE

ODONTOLOGIA DA

UN I VERS I DADE

Cidade de São

PAULO

2010; 22(1): 70-7, JAN - ABR 
TOLENTINO LS

TOLENTINO ES DIAS-RIBEIRO E

FRACASSO MLC QUEIROZ AF

PAVAN NNO

$A V U L S E D$

PERMANENT

INCISOR -

REPLANTATION

AFTER TWO DAYS

OF THE TRAUMA:

REPORT OF A

CASE

74

REVISTA DE

ODONTOLOGIA DA

UNIVERSIDADE

CIDADE DE SÃO

PAULO

2010; 22(1): $70-7$,

JAN-ABR shown that the greatest determinant for tooth survival is immediate replantation at the moment of the accident (Andreasen et al. ${ }^{21}$, 2002; Kenny e Casas ${ }^{14}$, 2005; Lekic et al. ${ }^{15}, 1998$; Walter et al. $\left.{ }^{22}, 2008\right)$. A delay greater than 5 minutes in the replantation (Toronto Dental Trauma Research Group $^{16}$, 2005) will lead to resorption and occasionally to loss of the tooth if it is not stored in an adequate medium (Andreasen et al. $\left.{ }^{17}, 1995\right)$.

These storage media are varied and widely discussed in the literature. Some authors (Andreasen et al. ${ }^{11}$, 2000; Cardoso e Gonçalves ${ }^{7}, 2002$; Soares e Goldberg ${ }^{5}$, 2001; Sonoda et al. ${ }^{19}$, 2008) agree that the avulsed tooth should be preferably stored in milk, because it preserves the cells on the root surface for up to 3 hours, present physiological properties, including its $\mathrm{pH}$ (6.5-7.2), and similar osmolality as the extracellular fluid (250-270 mOsm Kg-1), is easy to achieve and is relatively free of bacteria. The tooth may also be stored in Hank solution (Cardoso e Gonçalves ${ }^{7}$, 2002; Sonoda et al. ${ }^{19}, 2008$ ), yet this solution is usually not available at the side of the accident. Even though the saline presents better performance than dry storage, it should only be used when the aforementioned media are unavailable (Andreasen et al. ${ }^{11}, 2000$ ).

In the present case report, the time elapsed from the occurrence of trauma up to emergency care was 48 hours, worsened by the dry storage of the tooth, conditions reported in the scientific literature as unfavorable for a good prognosis. However, despite the unsatisfactory conditions, replantation was the treatment option due to the young age of the patient, and the family was informed on the risk of failure.

The procedure of late replantation is contraindicated by some authors. According to Kenny e Casas ${ }^{14}$ (2005), if the tooth remains outside the mouth for less than 5 minutes or is stored in a correct medium for up to half hour, it should be replanted. However, if the tooth is outside the socket for more than 5 minutes and is not stored in an appropriate liquid, it will probably be resorbed and occasionally lost.

According to Andreasen et al. ${ }^{17}$ (1995), even teeth kept dry for long periods should be replanted. In the case of late replantation, careful cleaning with gauze soaked in saline is recommended to remove the necrotic periodontal ligament fibers (Cardoso e Gonçalves $\left.{ }^{7}, 2002\right)$. Some authors suggest the use of substances for root surface treatment, such as sodium fluoride (Andreasen et al. ${ }^{17}, 1995$; Walton e Torabinejad $^{2}$, 1997), tetracycline (Andreasen et al. $\left.{ }^{21}, 2002\right)$, stannous fluoride, calcium hydroxide, formalin, alcohol and indomethacin. However, only sodium fluoride was able to inhibit the root resorption (Andreasen et al. ${ }^{17}, 1995$; Walton e Torabinejad $^{2}$, 1997). In the present case, due to the unavailability of this solution at the moment of care, the tooth was only cleaned with gauze soaked in saline.

Tooth replantation is often considered a temporary treatment, since $74-96 \%$ of these teeth present root resorption and are ultimately extracted.

According to Pohl et al. ${ }^{8}$ (2005), avulsed and replanted teeth may be lost 2 months after replantation or may survive for many years. Their study reveals that, according to the progression of root resorption in a replanted tooth, as analyzed on radiographs, complete root resorption occurred after 3-7 years in patients aged 8 to 16 years and after decades in older patients. Thus, there is consensus on the need to maintain the avulsed tooth in an adequate medium when there is no possibility of immediate tooth replantation.

In cases of avulsion and replantation, control of inflammation and repair of the periodontium are necessary (Pohl et al. ${ }^{13}$, 2005). The persistence of acute or chronic inflammation for long periods leads to the establishment of a favorable tissue environment that may stimulate the inflammatory resorption. Therefore, when replanting the tooth, simultaneous prescription of wide spectrum antibiotic therapy is recommended for two weeks. After this period, endodontic therapy is indicated.

The calcium hydroxide dressing was replaced in eight clinical sessions. This drug was used due to its ability to prevent the root resorption. The recent finding that the process of inflammatory resorption would be significantly related to the degree of pulp infection, the observation that 
most microorganisms found in these cases are anaerobes probably coming from the subgingival microbiota, and the actual antiseptic effectiveness of calcium hydroxide against these microorganisms lead to the assumption that this products presents the desirable conditions for utilization in these cases (Soares e Goldberg5, 2001).

In the present study, tooth replantation aimed at ankylosis of the avulsed tooth. It is known that ankylosis may affect the growth of the alveolar ridge and the eruption and position of adjacent teeth (Polat e Tacir ${ }^{4}, 2008$; Soares et al. ${ }^{6}, 2008$ ), yet this was the treatment option found to satisfy the patient. Also, in the long term, ankylosis allows bone formation by the replacement resorption and enhances the local conditions for future treatment with implants, after completion of facial growth and development.

Follow-up of the replanted tooth comprised weekly radiographic examination to evaluate the presence of inflammatory resorption and periapical lesion. Ankylosis could be radiographically and clinically observed after 10 months.

After 28 months, the tooth clinically exhibited normal aspect, and the radiographic examination revealed a slight alteration at the apical portion of the root, suggesting the onset of root resorption. Pohl et al. ${ }^{8}$ (2005) believe that there is no exact period for the onset of root resorption, whose occurrence varies between patients.

The time during which the tooth is maintained in the mouth is very impor- tant, because it maintains the height of the alveolar ridge (Cobankara e Ungor ${ }^{23}$, 2007). Also, from a psychological standpoint (Polat e Tacir ${ }^{4}$, 2008; Senes et al. ${ }^{1}$, 2008), it prepares the patient for an occasional tooth loss, and this period may correspond to completion of the growth period, allowing the definitive prosthetic treatment.

Considering the high rate of dentoalveolar trauma such as avulsion, it is advisable to establish prevention plans for these situations (Flores et al. ${ }^{24}, 2001$; Flores et al. ${ }^{10}$, 2007; Holan et al. $\left..^{25}, 2006\right)$. In addition to the Project CEMTrau, which aims at the rehabilitative treatment, the State University of Maringá also develops the project "Saving the traumatized tooth", which offers lectures and counseling to promote the awareness of the general community as to the management of dentoalveolar trauma, as well as the prevention of these cases.

\section{CONCLUSION}

This case report aimed to discuss a treatment option for tooth avulsion in young patients, with late replantation. Even though the conditions of care were considered unfavorable and contraindicated by the scientific literature and the prognosis was impaired, a considerable benefit was achieved for the patient, since the treatment allowed its immediate reintegration to the social relationships, as well as maintenance of facial growth and development, favoring the future rehabilitation of the patient with utilization of dental implant.
TOLENTINO LS

TOLENTINO ES

DIAS-RIBEIRO E

FRACASSO MLC

QUEIROZ AF

PAVAN NNO

AVULSED

PERMANENT

INCISOR -

REPLANTATION

AFTER TWO DAYS

OF THE TRAUMA:

REPORT OF A

CASE
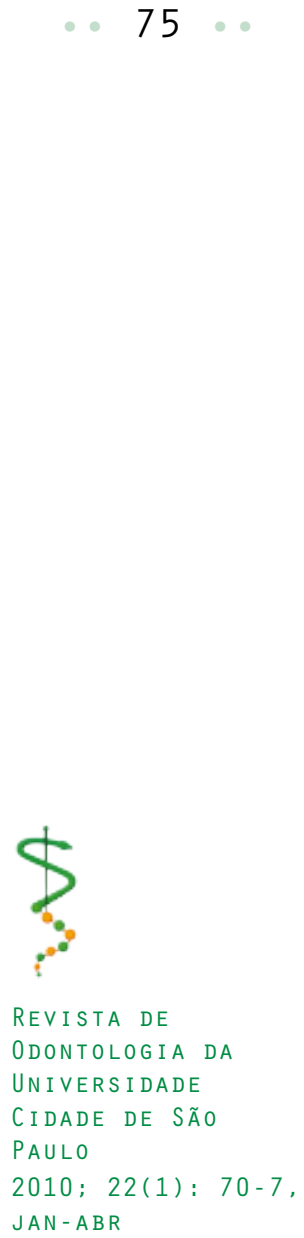
TOLENTINO LS

TOLENTINO ES

DIAS-RIBEIRO E

FRACASSO MLC

QUEIROZ AF

PAVAN NNO

$A \cup U L S E D$

PERMANENT

INCISOR -

REPLANTATION

AFTER TWO DAYS

OF THE TRAUMA:

REPORT OF A

CASE

76

\section{REFERENCES}

1. Senes AM, Sakai VT, Oliveira TM, Machado MA, Santos CF, Marzola C. Management of a multiple dentoalveolar trauma in permanent dentition with avulsion of a canine: a 4-year follow-up. J Endod 2008 Mar; 34(3):336-9.

2. Walton RE, Torabinejad M. Princípios e prática em Endodontia. 2th ed. São Paulo: Santos, 1997.

3. Chappuis V, von Arx T. Replantation of 45 avulsed permanent teeth: a 1-year followup study. Dent Traumatol 2005 Oct; 21(5):289-96.

4. Polat ZS, Tacir IH. Esthetic rehabilitation of avulsed-replanted anterior teeth: a case report. Dent Traumatol 2008 Jun; 24(3):e385-9.

5. Soares JI, Goldberg F. Endodontia: Técnicas e fundamentos. Porto Alegre: Artmed editora, 2001.

6. Soares Ade J, Gomes BP, Zaia AA, Ferraz CC, de Souza-Filho FJ. Relationship between clinical-radiographic evaluation and outcome of teeth replantation. Dent traumatol 2008 Apr; 24(2):183-8.

7. Cardoso RJA, Gonçalves EAN. 20 Arte ciência técnica. Odontologia 2. São Paulo: Artes Médicas, 2002.

8. Pohl Y, Filippi A, Kirschner H. Results after replantation of avulsed permanent teeth. I. Endodontic considerations. Dent Traumatol 2005 Apr; 21(2):80-92.

9. Consolaro A. Reabsorções dentárias. Maringá: Dental Press, 2005.

10. Flores MT, Andreasen JO, Bakland LK, Feiglin B, Gutmann JL, Oikarinen K, el al. Guidelines for the evaluation and management of traumatic dental injuries. Dent Traumatol 2001 Oct; 17(5):193-8.

11. Andreasen JO, Andreasen FM, Bakland LK, Flores MT. Manual de traumatismo dental. Porto Alegre: Artmed, 2000, 64 p.

12. Barret EJ, Kenny DJ, Tenenbaum HC, Sigal MJ, Johnston DH. Replantation of permanent incisors in children using Emdogain. Dent Traumatol 2005 Oct; 21(5):269-75.

13. Pohl Y, Filippi A, Kirschner H. Results after replantation of avulsed permanent teeth. II. Periodontal healing and the role of physiologic storage and antiresorptive-regenerative therapy. Dent Traumatol 2005 Apr; 21(2):93-101.

14. Kenny DJ, Casas MJ. Medicolegal aspects of replanting permanent teeth. J Can Dent Assoc 2005 Apr; 71(4):245-8.

15. Lekic PC, Kenny DJ, Barrett EJ. The influence of storage conditions on the clonogenic capacity of periodontal ligament cells: implications for tooth replantation. Int Endod J 1998 Mar; 31(2):137-40.

16. Toronto Dental Trauma Research Group. The knocked-out permanent tooth: information for patients, parents and caregivers. J Can Dent Assoc 2005 Apr; 71(4):248a, 248.

17. Andreasen JO, Borum MK, Jacobsen HL, Andreasen FM. Replantation of 400 avulsed permanent incisors. 4. Factors related to periodontal ligament healing. Endod Dent Traumatol 1995 Apr; 11(2):76-89.

18. Barret EJ, Kenny DJ. Avulsed permanent teeth: a review of the literature and treatment guidelines. Endod Dent Traumatol 1997 Aug; 13(4):153-63.

19. Sonoda CK, Poi WR, Panzarini SR., Sottovia AD, Okamoto T. Tooth replantation after keeping the avulsed tooth in oral environment: case report of a 3-year follow-up. Dent Traumatol 2008 Jun; 24(3):373-6. 
20. Pohl Y, Wahl G, Filippi A, Kirschner H.. Results after replantation of avulsed permanent teeth. III. Tooth loss and survival analysis. Dent Traumatol 2005 Apr; 21(2):10210.

21. Andreasen JO, Andreasen FM, Skeie A, Hjorting-Hansen E, Schwartz O. Effect of treatment delay upon pulp and periodontal healing of traumatic dental injuries - a review article. Dent Traumatol 2002 Jun; 18(3):116-28.

22. Walter C, Krastl G, Iziquierdo A, Hecker H, Weiger R. Replantation of three avulsed permanent incisors with complicated crown fractures. Int Endod J 2008 Apr; 41(4):356-64. Epub 2007 Dec 12.

23. Cobankara FK, Ungor M. Replantation after extended dry storage of avulsed permanent incisors: report of a case. Dent Traumatol 2007 Aug; 23(4):251-6.

24. Flores MT, Andersson L, Andreasen JO, Bakland LK, Malmgren B, Barnett F, et al. Guidelines for the managment of traumatic dental injuries. II. Avulsion of permanent teeth. Dent Traumatol 2007 Jun; 23(3):130-6.

25. Holan G, Cohenca N, Brin I, Sgan-Cohen H. An oral health promotion program for the prevention of complications following avulsion: the effect on knowledge of physical education teachers. Dent Traumatol 2006 Dec; 22(6):323-7.

Recebido em: 01/06/2009

Aceito em: 01/10/2009
TOLENTINO LS

TOLENTINO ES

DIAS-RIBEIRO E

fracasso mLC

QUEIROZ AF

PAVAN NNO

AVULSED

PERMANENT

INCISOR -

REPLANTATION

AFTER TWO DAYS

OF THE TRAUMA:

REPORT OF A

CASE

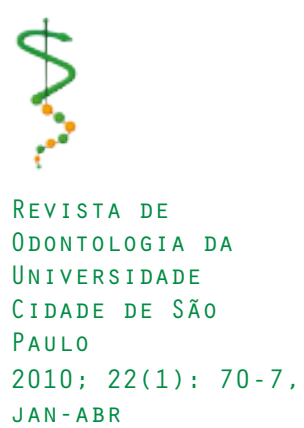

